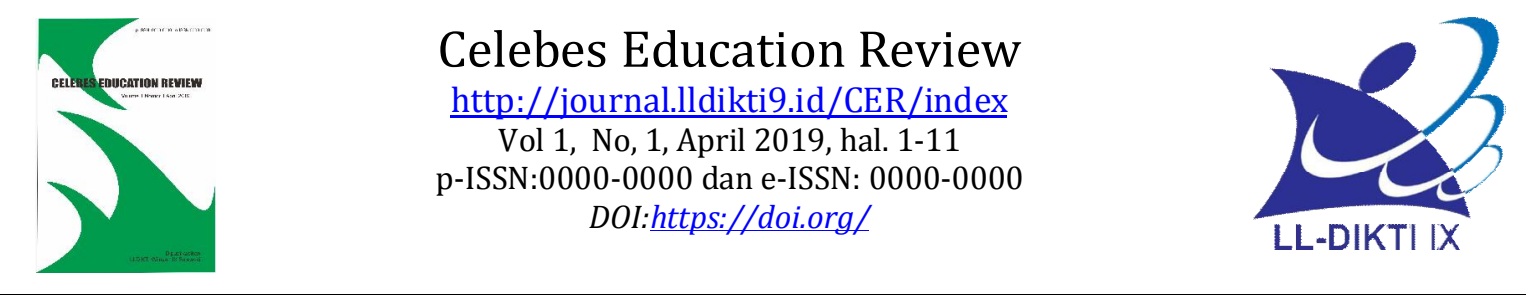

\title{
Improvement of Poetry Writing Skills by Using Clustering Technique of Class VIII Students of SMP Negeri 3 Alla, Enrekang District
}

\author{
Hernita Arifuddin 1 \\ ${ }_{1}^{1}$ AMI-AIPI Makassar \\ Email: etha99@rocketmail.com
}

\section{Artikel info}

Artikel history:

Received; 2 Maret 2019

Revised: 4 Maret 2019

Accepted;1 April 2019

\begin{abstract}
Abstrak
This research is a classroom action research which aims to improve poetry writing skills for class VIII students of SMP Negeri 3 Alla through clustering techniques. The subjects of this study were class VIII of State Junior High School 3 Alla who were enrolled in the 2011/2012 school year with 34 subjects. This research was conducted in 2 (two) cycles and each cycle was carried out in four meetings including the final test for each cycle. Data on student learning outcomes were analyzed by using quantitative analysis and data on student activities were analyzed by using qualitative analysis. The results of the study after the implementation of the action for two cycles, namely: (a) Increased poetry writing skills of students of class VIII.1 SMP Negeri 3 Alla after clustering techniques were applied in which in the first cycle obtained an average score of $58.82 \%$ in the medium category but have not yet achieved the minimum completeness criteria for writing poetry that is determined and experienced an increase in the second cycle of $73.23 \%$ in the high category and has achieved the minimum specified completeness criteria. From the results of this study it can be concluded that the clustering technique can improve poetry writing skills of class VIII students of SMP Negeri 3 Alla, Enrekang Regency.
\end{abstract}

Keywords:

Learning Outcomes,

Clustering Techniques
Coresponden author: Email: erni@gmail.com

lisensi CC BY -4.0

\section{PENDAHULUAN}

Seseorang harus memiliki keterampilan menulis untuk menunjang tugas-tugas keseharian yang terkait dengan kegiatan tulis menulis. Mulai dari penulisan laporan, pembuatan makalah, skripsi, tesis dan desertasi. Poerwadarminta (dalam Munirah, 2007:1) mengemukakan bahwa menulis selalu berurusan dengan bahasa. Hanya bahasalah satu-satunya rumusan untuk 


\section{| Celebes Education Journal}

menulis itulah sebabnya kecakapan menggunakan bahasa merupakan bekal yang utama. Sementara itu, dalam kamus besar bahasa Indonesia dijelaskan bahwa menulis adalah menyalurkan pikiran atau perasaan (seperti mengarang dan membuat surat) dengan tulisan (Alwi, dkk, 2002: 1221). Musabai (1989: 3) mendefinisikan menulis sebagai pelahiran atau pengungkapan pikiran dan perasaan melalui suatu lambang (tulisan). Tentu saja segala lambang (tulisan) yang dipakai haruslah merupakan hasil kesepakatan para pemakai bahasa yang satu dengan yang lainnya saling memahami. Apabila seseorang diminta untuk menulis, maka berarti dia akan mengungkapkan perasaannya ke dalam bentuk tulisan. Jadi, menulis itu berarti megungkapkan pikiran dengan tulisan. Setiap manusia selalu memiliki keinginan dan perasaan dalam berkegiatan setiap harinya. Perasaan yang kita rasakan dapat berupa hal yang menyenangkan, membahgiakan, menentramkan, atau sebaliknya menyedihkan, memalukan, kebencian, kegagalan, ketakutan, kekecewaan, putus asa, terhina, terancam, terasing, dan terkalahkan. Perasaan itu dapat diungkapkan sesuai dengan kemampuan atau bakat, kebiasaan, alat atau media yang kita miliki maupun yang biasa kita lakukan.

Secara etimologi, puisi berasal dari bahasa Yunani, yakni Poeima berarti membuat, Poiuisi yang berarti perbuatan atau Poeitis yang berarti membuat, membangun atau membentuk (Tengsoe, 1985: 50). Kosasih E. (2007:363) pendapat bahwa puisi adalah bentuk karya sastra yang mempergunakan kata-kata indah dan kaya makna. Ini berarti bahwa puisi itu karya estetis uang yang bermakna, yang mempunyai arti, bukan hanya sesuatu yang kosong tanpa makna. Bebrapa para ahli telah memberikan batasan tentang puisi. Sembodo Edy (2009:20) meengatakan bahwa puisi adalah ungkapan imajinatif yang dirangkai dengan irama dan memperhatikan pemaknaan.

Sementara itu menurut Aminuddin (1999: 134) bahwa etimologi, puisi berarti "membuat" atau "perbuatan" sebab melalui puisi pada dasarnya seseorang berada pada suatu dunia tersendiri yang mungkin berisi pesona atau gambaran suasana tertentu baik fisik maupun batiniah.

Dalam standar kompetensi pembelajaran Bahasa dan Sastra Indonesia SMP kelas VIII terdapat sepuluh kompetensi dasar untuk aspek menulis. Enam diantaranya untuk kemampuan menulis bahasa dan empat untuk keterampilan menulis sastra. Salah satu kompetensi dasar menulis sastra pada kelas VIII semester 2 adalah menulis puisi. Kompetensi dasar ini dipilih oleh peneliti disebabkan peneliti berminat pada puisi karena dari pengalamannya peneliti mendapat gambaran bahwa puisi menarik. Selain itu, terdapat kesenjangan antara apa yang diharapkan peneliti dan apa yang terjadi.

Kesenjangan itu terjadi dalam hal keterampilan menulis merupakan keterampilan yang produktif dan sangat penting karena merupakan keterampilan yang harus dimiliki oleh siswa. Namun, dalam implementasi pembelajaran bahasa Indonesia di sekolah banyak ditemukan kesulitan siswa dalam menulis puisi. Banyak siswa mengeluh saat mereka ditugaskan untuk menulis puisi. Hal ini dikarenakan mereka menganggap menulis puisi itu merupakan hal yang sulit dan tidak penting. Kesulitan yang mereka hadapi diantaranya dalam menentukan tema, memilih diksi, dan merangkai kata. Kurangnya teknik yang efektif untuk menulis puisi dan kurangnya evaluasi untuk penulisan puisi menjadi penyebab hal di atas. Selain itu, guru terlalu banyak menyampaikan teori tentang puisi bukan praktik menulis puisi sehingga siswa merasa bosan, menganggap dirinya tidak memiliki kemampuan menulis puisi dan siswa hanya memiliki pengetahuan tentang puisi bukan keterampilan menulis puisi. Padahal sebenarnya menulis puisi itu penting dan tidak terlalu sukar karena termasuk jenis keterampilan. Seperti halnya dengan 
keterampilan yang lain pemerolehannya harus melalui belajar dan berlatih. Makin sering belajar dan makin giat berlatih tentu makin cepat terampil. Menulis puisi juga dapat dijadikan kegiatan yang menyenangkan dalam mengungkapkan perasaan dan pikiran serta menumbuhkan kebiasaan positif kepada siswa agar kreatif menuangkan ide dan perasaannya ke dalam sebuah wadah yang indah dan bernilai. Puisi layaknya lukisan yang dapat memuaskan perasaan pembuatnya dan menciptakan suatu nilai rasa tertentu bagi para penikmatnya. Selain itu, dengan menulis puisi dapat membuat hati kita menjadi peka dan bias mengontrol emosi karena seperti yang dikemukakan oleh Ralph Waldo Emerson yang menjelaskan bahwa puisi merupakan upaya abadi untuk mengekspresikan jiwa sesuatu, untuk menggerakkan tubuh yang kasar dan mencari kehidupan dan alasan yang menyebabkannya ada ( Tarigan, 1984:4).

Pembelajaran menulis puisi di SMP selain bertujuan menggali dan mengembangkan kompetensi dasar siswa dalam mengapresiasikan sastra, juga melatih keterampilan siswa menggali nilai-nilai yang terkandung dalam puisi sehingga dapat menciptakan puisi-puisi yang bermutu.

Berdasarkan observasi, pada kelas VIII SMP Negeri 3 Alla Kabupaten Enrekang, rata-rata keterampilan menulis puisi siswa sangat rendah dapat dibuktikan dengan berdasarkan rata-rata nilainya 6. Rendahnya keterampilan menulis puisi pada siswa kelas VIII SMP Negeri 3 Alla Kabupaten Enrekang salah satu factor utamanya adalah teknik yang digunakan dalam pembelajaran.

Dari permasalahan dan alasan itu peneliti mencoba mencari solusi dari masalah di atas melalui teori-teori yang telah ada untuk diramu dan disajikan lebih baik. Solusi yang disajikan dalam penelitian ini adalah teknik Clustering (pengelompokkan ide). Penelitian ini menitikberatkan teknik clustering dalam pembelajaran menulis puisi karena teknik clustering digunakan untuk mengatasi hambatan dalam aktivitas menulis yang sering dialami oleh siswa.

Adapun alasan-alasan yang mengakibatkan peneliti beranggapan bahwa dengan teknik clustering akan memudahkan siswa, karena akan terdorong menulis puisi dan mengekspresikan perasaannya setelah menuangkan ide-ide mereka di atas sebuah kertas. Teknik clustering mampu mengaktifkan peranan otak kanan sebagai munculnya ide-ide baru yang bergairah dan emosi yang kerap diabaikan fungsinya. Teknik Clustering dikembangkan oleh seorang penulis dan peneliti yang bernama Dr. Gabriele L.Rico. Teknik Clustering merupakan salah satu dari teknik belajar yang bermetodekan Quantum Learning. Metode belajar Quantum Learning dikemukakan oleh Bobbi DePorter dan Mike Hernacki yang pada awalnya bertolak pada konsep suggestopedia. Teknik Clustering adalah suatu teknik memilah pemikiran-pemikiranyang saling berkaitan dan menuangkannya di atas kertas secepatnya, tanpa mempertimbangkan kebenaran atau nilainya (DePotter, 2000:181).

Menurut (DePorter, 2000:180) Teknik Clustering adalah suatu cara memilah pemikiranpemikiran yang saling berkaitan dengan menuangkannya di atas kertas, tanpa mempertimbangkan kebenaran atau nilainya. Artinya sebuah pemikiran yang dikelompokkan di atas kertas hampir sama seperti proses berpikir yang terjadi dalam otak, walaupun dalam bentuk yang disederhanakan. Selain itu DePorter (2000:184) mengatakan bahwa metode pengelompokkan ide ( Clustering) dapat digunakan untuk segala jenis tulisan, dari laporan, esai, proposal hingga puisi dan cerita. Teknik clustering ini juga sangat berguna untuk mengembangkan ide yang biasa-biasa saja menjadi ide yang luar biasa. Dengan teknik clustering, ide yang telah dibuat bisa menjadi ide yang bercabang-cabang. Terkadang, sifat pengembangan ide ini benar-benar bebas memanfaatkan otak kanan yang menyukai kebebasan yang bersimbolkan gambar. 


\section{| Celebes Education Journal}

Berdasarkan pemaparan di atas peneliti berasumsi bahwa pembelajaran menulis puisi akan lebih baik lagi jika menggunakan teknik pembelajaran yang menarik, yang menggetarkan perasaan, yang mampu mewadai kreatifitas siswa dan mudah dipahami siswa. Menulis puisi dipilih dalam penelitian ini disebabkan menulis puisi selama ini masih kurang efektif, kurang mengarahkan seluruh kemampuan siswa dan kurang memperhatikan minat siswa sehingga siswa tidak menyenangi kegiatan menulis puisi.

Oleh karena itu, peneliti mengajukan teknik clustering sebagai solusi dari beberapa masalah yang telah disebutkan. Teknik clustering ini digunakan untuk dapat memberikan arahan kepada siswa dalam mengelompokkan ide dalam penulisan puisi yang menarik menurut siswa, menggunakan otak kanan siswa yang menyukai kebebasan yang bersimbolkan gambar.

\section{METODOLOGI PENELITIAN}

Penelitian ini dilaksanakan di SMP Negeri 3 Alla Kabupaten Enrekang pada tahun ajaran 2012/2013 semester ganjil. Subjek dalam penelitian ini adalah kelas VIII SMP Negeri 3 Alla Kabupaten Enrekang dengan jumlah siswa 34 orang. Penelitian ini merupakan penelitian tindakan kelas yang bertujuan untuk meningkatkan kemampuan menulis puisi siswa kelas VIII SMP Negeri 3 Alla Kabupaten Enrekang melalui teknik Clustering dengan tahapan-tahapan pelaksanaan meliputi perencanaan, tindakan, observasi dan refleksi. Selanjutnya, tahapantahapan tersebut dirangkai dalam satu siklus kegiatan. Penelitian ini diarahkan untuk memecahkan masalah atau perbaikan yang berhubungan dengan masalah-masalah dikelas. Penelitian ini difokuskan kepada perbaikan proses maupun peningkatan hasil kegiatan. Penelitian ini dilaksanakan di SMP Negeri 3 Alla Kabupaten Enrekang pada tahun ajaran 2012/2013 semester ganjil. Jenis data yang didapatkan dalam penelitian ini adalah data kualitatif dan data kuantitatif.

1) Data kualitatif yaitu data yang diperoleh dari aktifitas siswa dan akifitas guru berupa data hasil observasi dan hasil wawancara.

2) Data kuantitatif yaitu data yang diperoleh dari hasil menulis puisi siswa

Data yang dibutuhkan dalam penelitian, maka harus diberikan tes berupa tes menulis puisi, tes digunakan untuk mengetahui peningkatan menulis puisi melalui pengamatan objek secara langsung. Kegiatan observasi merupakan kegiatan peneliti dengan cara mengamati aktivitas siswa selama mengikuti proses pembelajaran menulis puisi dengan menggunakan teknik Clustering pada siswa kelas VIII SMP Negeri 3 Alla Kabupaten Enrekang. Analisis data hasil penelitian menggunakan analisis deskriptif kualitatif untuk mendeskripsikan keterampilan menulis puisi pada siswa SMP Negeri 3 Alla Kabupaten Enrekang dengan menggunakan teknik Clustering pada setiap siklus. Selanjutnya, pengujian hipotesis dilakukan dengan cara membandingkan nilai rata-rata hasil tes siklus pertama dan kedua. Kategori keterampilan menulis puisi siswa, diklasifikasikan atas 5 kategori, yaitu, Indikator keberhasilan penelitian ini adalah terjadinya perubahan sikap siswa terhadap bahan ajar dalam proses belajar mengajar dan dari segi hasil belajar, serta peningkatan skor rata-rata hasil belajar siswa dalam menulis puisi melalui teknik clustering. Siswa dikatakan tuntas apabila memperoleh skor minimal 65 dari skor ideal. Dan tuntas secara klasikal apabila 80\% dari jumlah siswa yang telah tuntas belajar. 


\section{HASIL PENELITIAN DAN PEMBAHASAN}

Hasil penelitian tindakan kelas ini telah dilaksanakan pada siswa kelas VIII SMP Negeri 3 Alla Kabupaten Enrekang dari bulan oktober sampai dengan bulan Desember 2012, dilaksanakan setiap hari selasa dan kamis dengan waktu pembelajaran yang digunakan pukul 07.30-09.30 Wita. Metode pelaksanaannya mengikuti prinsip-prinsip penelitian tindakan kelas terdiri dari siklus 1 dan siklus II, meliputi perencanaan pelaksanaan tindakan, observasi, dan refleksi. Data hasil penelitian diperoleh dari dua bagian yaitu data kualitatif sesuai dengan bentuk Instrumen pengumpulan data yang digunakan yaitu observasi dan dokumentasi.

Hasil penelitian yang diperoleh dari penelitian ini dianalisis secara deskriptif kualitatif. Analisis deskriptif kualitatif digunakan untuk menganalisis data tentang perubahan sikap siswa. Adapun yang dianalisis adalah hasil belajar tes siklus 1 dan siklus II, serta data tambahan berupa tanggapan yang diberikan oleh siswa selama penelitian berlangsung. Data tersebut dibuatkan daftar tabel lalu diberi nilai dan dihitung nilai frekuensinya dan presentasenya kemudian menjadi sumber acuan untuk intrepretasi dalam bentuk analisis deskriptif kualitatif.

\section{Hasil Penelitian Siklus 1}

a. Perencanaan

Kegiatan yang dilaksanakan pada tahap perencanaan penelitian tindakan kelas pada siklus pertama dalam pembelajaran menulis puisi di kelas VIII.1 SMP Negeri 3 Alla Kabupaten Enrekang yaitu melaksanakan observasi awal pada kelas tempat penelitian, mengadakan sosialisasi rencana dan maksud penelitian untuk memaksimalkan hasil dan keterlibatan siswa dan guru. Menelaah kurikulum SMP kelas VIII semester genap mata pelajaran bahasa Indonesia, membuat perangkat pembelajaran pada setiap pertemuan yang terdiri dari Rencana pelaksanaan Pembelajaran (LKS), menyusun lembar observasi aktivitas mengajar guru dan aktivitas belajar siswa dalam mengikuti pelajaran bahasa Indonesia, menyusun format penilaian kemampuan menulis puisi, menetapkan jadwal pembelajaran bahasa Indonesia sebanyak 2 pertemuan setiap siklus, menetapkan indikator keberhasilan pembelajaran bahasa Indonesia dengan materi menulis puisi dengan menggunakan teknik Clustering 61-80 (baik).

\section{b. Pelaksanaan Tindakan}

Pelaksanaan pembelajaran bahasa Indonesia pada siklus pertama di kelas VIII.1 SMP Negeri 3 Alla Kabupaten Enrekang sebanyak 2 pertemuan. Kegiatan yang dilaksanakan pada tahap pelaksanaan dalam pembelajaran bahasa Indonesia dengan menggunakan teknik Clustering adalah sebagai berikut:

1) Kegiatan awal

Kegiatan awal yang dilakukan oleh guru dalam pembelajaran bahasa Indonesia tentang penggunaan teknik Clustering dalam meningkatkan keterampilan menulis puisi, yaitu berdoa, mengabsen siswa, menyampaikan SK, KD dan tujuan pembelajaran yang ingin dicapai dan apersepsi.

2) Kegiatan Inti

Peningkatan keterampilan menulis puisi dilakukan melalui penggunaan teknik Clustering siswa kelas VIII SMP Negeri 3 Alla Kabupaten Enrekang. Kegiatan yang dilaksanakan pada kegiatan inti yaitu guru menjelaskan mengertian puisi dan unsure-unsur puisi dan siswa mengamati penjelasan contoh puisi, siswa memperlihatkan objek yang akan diamati, dan siswa mengamati dan mencatat apa yang dilihat pada objek pengamatan.

3) Kegiatan Akhir

Kegiatan akhir yang dilakukan adalah siswa dan guru merangkum materi pelajaran, siswa dan guru melakukan refleksi, guru memberikan tugas rumah, guru menutup pelajaran dan memberiakn pesan-pesan moral.

\section{c. Observasi dan Evaluasi}




\section{| Celebes Education Journal}

Hasil pengamatan/observasi pada Kelas VIII SMP Negeri 3Alla Kabupaten Enrekang dapat dilihat mengenai aktivitas siswa selama proses pembelajaran berlangsung pada siklus I dapat dilihat pada lampiran dan dapat dijelaskan sebagai berikut:

a. Persentase kehadiran siswa pada siklus I mencapai $88.23 \%$

b. Siswa yang membuat puisi dengan menggunakan teknik Clustering $61.76 \%$

c. Siswa yang aktif bekerja sama antarsiswa $61,76 \%$

d. Siswa yang aktif berpartisipasi dalam proses pembelajaran $67,64 \%$

e. Siswa yang aktif memperhatikan penjelaskan teknik clustering $73,52 \%$

f. Siswa yang aktif dalam berkonsentrasi menulis puisi $64,70 \%$

skor nilai rata-rata kemampuan menulis puisi dengan menggunakan teknik clustering pada siswa kelas VIII.1 SMP Negeri 3 Alla Kabupaten Enrekang pada siklus 1 58,82. Skor yang dicapai responden tersebar dengan nilai tertinggi 80 dan skor terendah 40 dari skor tertinggi yang mungkin dicapai 100 dan skor terendah yang mungkin dicapai 0 . Hal ini menunjukkan bahwa tingkat kemampuan siswa menulis puisi cukup bervariasi. Kategori keterampilan menulis puisi dengan menggunakan teknik clustering pada siswa kelas VIII SMP Negeri 3 Alla Kabupaten Enrekang diklasifikasikan atas 5 kategori yaitu sangat tinggi, tinggi, sedang, rendah, dan sangat rendah

Berdasarkan data, maka dapat diketahui bahwa dari 34 orang siswa yang mengikuti pembelajaran menulis puisi dengan menggunakan teknik clustering pada siklus pertama, tidak ada siswa atau $0 \%$ pada kategori sangat rendah; 5 orang siswa atau dengan persentase $14,70 \%$ siswa memperoleh nilai dengan kategori rendah; 19 orang siswa atau dengan persentase 55,88\% siswa memperoleh nilai dengan kategori sedang; 10 orag siswa atau dengan persentase $29,41 \%$ siswa memperoleh nilai dengan kategori tinggi; dan tidak ada siswa atau $0 \%$ pada kategori sangat tinggi.

\section{d. Refleksi}

Karena keterampila menulis puisi siswa pada akhir Siklus I belum menunjukkan hasil yang optimal dan belum meratanya pemahaman siswa terhadap teknik Clustering maka dasar acuan ini dilanjutkan pelaksanaan tindakan pada Siklus II dengan lebih meningkatkan keaktifan siswa dengan cara memperbanyak latihan.

\section{Hasil Penelitian Siklus II}

a. Perencanaan

Kegiatan yang dilaksanakan pada tahap perencanaan penelitian tindakan kelas pada siklus kedua dalam pembelajaran menulis puisi di kelas VIII.1 SMP Negeri 3 Alla Kabupaten Enrekang yaitu menyusun rencana pelaksanaan pembelajaran (RPP) dan Lembar Kegiatan Siswa (LKS), menyusun lembar observasi aktivitas mengajar guru dan aktivitas belajar siswa dalam mengikuti pelajaran bahasa Indonesia, menyusun format penilaian keterampilan menulis puisi, menetapkan jadwal pembelajaran bahasa Indonesia sebanyak 2 pertemuan setiap siklus, menetapkan indicator keberhasilan pembelajaran bahasa Indonesia dengan materi menulis puisi dengan teknik Clustering 61,80 (baik).

\section{b. Pelaksanaan Tindakan}

Pelaksanaan pembelajaran bahasa Indonesia pada siklus kedua di kelas VIII.1 SMP Negeri 3 Alla kabupaten Enrekang sebanyk 2 pertemuan. Kegiatan yang dilakukan pada tahap pelaksanaan dalam pembelajaran bahasa Indonesia dengan menggunakan teknik Clustering adalah sebagai berikut;

\section{1) Kegiatan Awal}

Kegiatan awal yang dilakukan oleh guru dalam pembelajaran bahasa Indonesia tentang penggunaan teknik Clustering dalam meningkatkan keterampilan menulis puisi, yaitu berdoa, 
mengabsen siswa, menyampaikan SK, KD dan tujuan pembelajaran yang ingin dicapai dan apersepsi.

\section{2) Kegiatan Inti}

Peningkatan keterampilan menulis puisi dilakukan melalui penggunaan teknik Clustering siswa kelas VIII SMP Negeri 3 Alla Kabupaten Enrekang. Kegiatan yang dilaksanakan pada kegiatan inti yaitu guru menjelaskan mengertian puisi dan unsure-unsur puisi dan siswa mengamati penjelasan contoh puisi, siswa memperlihatkan objek yang akan diamati, dan siswa mengamati dan mencatat apa yang dilihat pada objek pengamatan.

\section{3) Kegiatan Akhir}

Kegiatan akhir yang dilakukan adalah siswa dan guru merangkum materi pelajaran, siswa dan guru melakukan refleksi, guru memberikan tugas rumah, guru menutup pelajaran dan memberiakn pesan-pesan moral.

\section{c. Observasi dan Evaluasi}

Hasil pengamatan pada Kelas VIII SMP Negeri 3 Alla Kab. Enrekang dapat dilihat mengenai aktivitas siswa selama proses pembelajaran berlangsung pada siklus II dan dijelaskan sebagai berikut:

a. Persentase kehadiran siswa pada siklus I mencapai $100 \%$

b. Siswa yang mampu membuat puisi dengan menggunakan teknik Clustering mencapai $79,41 \%$

c. Siswa yang aktif bekerjasama antarsiswa $76,47 \%$

d. Siswa yang aktif berpartisipasi dalam pembelajaran $86,76 \%$

e. Siswa yang aktif memperhatikan menjelasan teknik clustering 88,235

f. Siswa yang aktif dalam berkonsentrasi menulis puisi $91,17 \%$

Dari data menunjukkan bahwa pada siklus II persentase ketuntasan siswa sebanyak 27

orang atau $79,41 \%$ siswa yang mencapai kategori tuntas, sedangkan senyak 7 orang atau $20,58 \%$ siswa yang berada dalam kategori tidak tuntas. Artinya, siswa yang mencapai nilai dengan kategori tuntas mengalami peningkatan.

\section{d. Refleksi}

Berdasarkan hasil observasi dan hasil tes keterampilan menulis puisi siswa kelas VIII.1 SMP Negeri 3 Alla Kab. Enrekang, maka dilakukan refleksi yaitu hasil observasi menunjukkan bahwa aktivitas belajar siswa dalam menulis puisi dengan menggunakan teknik clustering pada siklus kedua mengalami peningkatan. Siswa lebih aktif dalam pembelajaran terlihat pada keseriusan siswa dalam menerima materi. Selain itu, siswa juga lebih aktif dalam kegiatan Tanya jawab dan memberikan kesimpulan pda saat akhir pembelajaran. Dengan menggunakan teknik clustering siswa lebih aktif, kreatif, dan komunikatif dalam kegiatan pembelajaran menulis puisi, siswa yang masih kurang memahami materi pelajaran secara perlahan dapat memahami dengan sendirinya dengan menggunakan teknik clustering.

Peningkatan hasil belajar siswa dapat dilihat dari rata-rata hasil belajar siswa kelas VIII.1 SMP Negeri 3 Alla Kabupaten Enrekang, dimana pada siklus pertama skor rata-rata yang diperoleh siswa adalah 58,82\% dan pada siklus kedua 73,23\%. Berdasarkan tabel distribusi skor menulis puisi pada siklus pertama dan kedua dapat dilihat adanya peningkatan, dimana pada siklus 1 yaitu tidak ada siswa $(0 \%)$ dalam kategori sangat rendah, 5 siswa $(14,70 \%)$ dalam kategori rendah, 19 siswa(55,88\%) dalam kategori sedang, 10 siswa $(29,41 \%)$ dalam kategori tinggi, dan tidak ada siswa (0\%) dalam kategori sangat tinggi. Jadi pada siklus 1 dapat disimpulkan bahwa masih berada dalam kategori rendah. Upaya untuk meningkatkan keterampilan menulis puisi melalui teknik clustering siswa kelas VIII.1 SMP Negeri 3 Alla Kabupaten Enrekang pada siklus 1 belum tercapai secara optimal. Dengan demikian diadakan siklus II. Pelaksanaan siklus II diperoleh dari hasil tes siswa kelas VIII.1 SMP Negeri 3 Alla Kabupaten Enrekang, tidak ada siswa (0\%) yang ada dalam kategori sangat rendah, tidak ada siswa $(0 \%)$ yang ada dalam kategori rendah, 7siswa (20,58\%) yang ada dalam kategori sedang, 22 siswa $(64,70 \%)$ yang ada dalam kategori tinggi, 5 siswa $(14,70 \%)$ berada dalam kategori 


\section{| Celebes Education Journal}

sangat tinggi. Peningkatan hasil belajar dan keterampilan menulis puisi dengan menggunakan teknik clustering siswa kelas VIII.1 SMP Negeri 3 Alla Kabupaten Enrekang dapat dilihat pada siklus II dilakukan beberapa tindakan dengan melakukan perbaikan dari hasil refleksi siklus 1. Dengan menggunakan teknik clustering siswa lebih aktif, kreatif dan inovatif dalam kegiatan pembeljaran menulis puis, siswa yang masih kurang memahami materi pelajaran, secara perlahan dapat memahami dengan sendirinya setelah menggunakan teknik clustering.

\section{Pembahasan}

Kemampuan menulis puisi siswa merupakan salah satu aspek kemampuan berbahasa yang sangat penting dimiliki oleh setiap siswa sebagai suatu kegiatan mengekspresikan pikiran, gagasan, dan perasaan dalam bentuk menulis puisi. Peningkatan menulis puisi pada siswa menjadi tanggung jawab guru mata pelajaran bahasa Indonesia dalam melatih dan membimbing siswa dalam menulis puisi dengan melakukan inovasi pembelajaran, diantaranya adalah menggunakan teknik pembelajaran yang relevan dengan tuntutan materi pelajaran menulis, yaitu teknik clustering.

Berdasarkan uraian hasil penelitian menunjukkan bahwa ada peningkatan hasil belajar siswa dan perubahan sikap siswa kelas VIII.1 SMP Negeri 3 Alla Kabupaten Enrekang setelah diterapkan teknik clustering khusus pada guru mata pelajaran bahasa Indonesia, dilihat dari hasil tes siswa dan lembar observasi.

Peningkatan hasil belajar siswa dapat dilihat dari rata-rata hasil belajar siswa kelas VIII.1 SMP Negeri 3 Alla Kabupaten Enrekang, dimana pada siklus pertama skor rata-rata yang diperoleh siswa adalah 58,82\% dan pada siklus kedua 73,23\%. Berdasarkan tabel distribusi skor menulis puisi pada siklus pertama dan kedua dapat dilihat adanya peningkatan, dimana pada siklus 1 yaitu tidak ada siswa (0\%) dalam kategori sangat rendah, 5 siswa $(14,70 \%)$ dalam kategori rendah, 19 siswa(55,88\%) dalam kategori sedang, 10 siswa $(29,41 \%)$ dalam kategori tinggi, dan tidak ada siswa (0\%) dalam kategori sangat tinggi. Jadi pada siklus 1 dapat disimpulkan bahwa masih berada dalam kategori rendah.

Upaya untuk meningkatkan keterampilan menulis puisi melalui teknik clustering siswa kelas VIII.1 SMP Negeri 3 Alla Kabupaten Enrekang pada siklus 1 belum tercapai secara optimal. Dengan demikian diadakan siklus II.

Pelaksanaan siklus II diperoleh dari hasil tes siswa kelas VIII.1 SMP Negeri 3 Alla Kabupaten Enrekang, tidak ada siswa (0\%) yang ada dalam kategori sangat rendah, tidak ada siswa (0\%) yang ada dalam kategori rendah, 7siswa (20,58\%) yang ada dalam kategori sedang, 22 siswa $(64,70 \%)$ yang ada dalam kategori tinggi, 5 siswa $(14,70 \%)$ berada dalam kategori sangat tinggi.

Peningkatan hasil belajar dan keterampilan menulis puisi dengan menggunakan teknik clustering siswa kelas VIII.1 SMP Negeri 3 Alla Kabupaten Enrekang dapat dilihat pada siklus II dilakukan beberapa tindakan dengan melakukan perbaikan dari hasil refleksi siklus 1.

Dengan menggunakan teknik clustering siswa lebih aktif, kreatif dan inovatif dalam kegiatan pembeljaran menulis puis, siswa yang masih kurang memahami materi pelajaran, secara perlahan dapat memahami dengan sendirinya setelah menggunakan teknik clustering.

Berdasarkan uraian di atas dapat disimpulkan bahwa keterampilan menulis puisi dengan menggunakan teknik clustering pada siswa kelas VIII.1 SMP Negeri 3 Alla Kabupaten Enrekang dapat ditingkatkan dengan menerapkan teknik clustering. Hal ini dapat dilihat dari hasil belajar siswa kelas VIII.1 SMP Negeri 3 Alla Kabupaten Enrekang dapat tercapai dengan optimal. 


\section{KESIMPULAN DAN SARAN}

Berdasarkan hasil penelitian pada siswa kelas VIII SMP Negeri 3 Alla Kabupaten Enrekang dapat disimpulkan bahwa keterampilan menulis puisi dengan menggunakan teknik clustering pada siswa kelas VIII SMP Negeri 3 Alla Kabupaten Enrekang meningkat signifikan yaitu terlihat dari perolehan nilai rata-rata keterampilan menulis puisi siswa pada siklus I yaitu sebanyak 10 orang siswa dari 33 orang siswa atau 30,5\% sedangkan pada siklus II sebanyak 22 orang siswa atau $67 \%$.

Saran

Berdasarkan hasil penelitian tindakan kelas yang diperoleh dalam penelitian ini, maka saran yang dapat penulis kemukakan adalah sebagai berikut:

1. Guru hendaknya memperhatikan penggunaan teknik pembelajaran dalam mendukung peningkatan kualitas pembelajaran seperti penggunaan teknik Clustering yang efektif dalam meningkatkan pembelajaran keterampilan menulis puisi siswa. Oleh karena itu, guru harus berpikir kreatif dan inovatif dalam mempersiapkan teknik pembelajaran sesuai dengan tuntutan materi pembelajaran dan menekankan keaktifan siswa dalam belajar.

2. Siswa hendaknya berlatih menulis puisi sebagai bentuk mengekspresikan pikiran, ide, perasaan dalam bentuk tulisan sehingga dapat meningkatkan kemampuan belajarnya.

\section{UCAPAN TERIMA KASIH}

Proses penyelesaian jurnal ini dilalui oleh penulis dengan segala keterbatasan, baik kemampuan maupun pengalaman. Namun semuanya dapat diselesaikan berkat bantuan dan dorongan berbagai pihak sehingga hambatan dan kesulitan dapat diatasi. Oleh karena itu patut, kiranya jika dalam kesempatan ini penulis menghaturkan ucapan terimakasih yang sebesarbesarnya kepada Ayahanda Puang Arifuddin Aga dan Ibunda Puang Ani Palangi tercinta, yang memberi pengorbanan mulia demi masa depan serta senantiasa berdoa yang menjadi penerang langkah penulis dalam mencapai cita-cita. Hanya Allah yang bisa memberi balasan yang setimpal.

Dengan penuh kerendahan hati tak lupa penulis menyampaikan ucapan terimakasih dan penghargaan yang setinggi-tingginya kepada: Drs. Sahida, MM., Kepala sekolah SMP Negeri 3 Alla dan Alpiani, S.Pd, guru mata pelajaran bahasa indonesia atas bantuannya selama penulis mengadakan penelitian. Suami tercinta Dr. H. Muchriady Muchran, S.Kom,. M.M., yang selalu mendoakan, memberikan support dan dorongan sehingga penulis dapat menyelesaikan jurnal ini. Spesial buat ananda Adita Maghfira Athaya Muchriady dan Ainiyah Azqiarah Muchriady, terima kasih anakku sayang sudah mendoakan ibu. Mertua tersayang Dr. H. Muchran BL, S.E M.Si, dan Dra. Hj. Nurdiana Nurdin, M.M,. yang senantiasa mendoakan dan memberikan support kepada penulis. Kakak tersayang Andryani Arifuddin, S.E., Hajarullah Arifuddin, Rahma Arifuddin, S.Pd., Arimansyah Arifuddin, S. an terima kasih atas doanya. Kakak ipar H. Murniady Muchran, S.E., M.M., dan Hj. Muchriana Muchran, S.E,. M. AK, AK., dan adek ipar H. Masteriady Muchran, S.H., Mkn dan Hj. Monadillah Muchran. S.Fam., Apt. terima kasih atas semua doanya. Terima Kasih kepada Prof. DR. H. Muh. Yunus Sain, MA., dan Prof. DR. Hj. Rahmatia Yunus, MA., atas nasehat-nasehat dan dukungannya selama penulis menyusun jurnal ini.

\section{DAFTAR PUSTAKA}

Alwi, Hasan dkk. 2002. Tata Bahasa Baku Bahasa Indonesia. Jakarta : Balai Pustaka. Aminuddin. 1999. Pengantar Apresiasi Karya Sastra. Malang: Sinar Baru Algesindo.

De Porter, B dan Hernacki, M. 2000. Quantum Learning: membiasakan belajar nyaman dan menyenangkan. Bandung: Khaifa.

http://beautycha.blogspot.com/2012/01/teknik-clustering-dalam-pembelajaran.html Kosasih, E. 2007. 1700 Bank Soal Bintap Bahasa Indonesia. Bandung: Yrama Widya Munirah. 2007. Dasar Keterampilan Menulis. Diklat: UNISMUH. 


\section{| Celebes Education Journal}

Musabai, Zulkifli. 1989. Penuntun Tulis Menulis. Banjarmasin : Aulia.

Sembodo, Edy. 2009. Contekan Pintar Satra Indonesia. Jakarta: Hikmah

Tarigan, H.G dan Djago Tarigan. (1984). Keterampilan Berbahasa dan Komponen-Komponennya. Bandung: Angkasa

Tengsoe, TJ. 1985. Sastra Indonesia Pengantar Teori. Flores: Nusa Indah. 